\title{
Capital Asset Pricing Model, Theory and Practice: Evidence from USA (2009-2016)
}

\author{
Mohammad Abdel Mohsen Al-Afeef ${ }^{1}$ \\ ${ }^{1}$ Head of Finance \& Banking Department, Faculty of Economics \& Administrative Science, Jerash Private \\ University, Jerash, Jordan \\ Correspondence: Mohammad Abdel Mohsen Al-Afeef, Head of Finance \& Banking Department, Faculty of \\ Economics \& Administrative Science, Jerash Private University, Jerash, Jordan. E-mail: afeif500@yahoo.com
}

Received: June 4, 2017

Accepted: July 10, 2017

Online Published: July 18, 2017

doi:10.5539/ijbm.v12n8p182

URL: https://doi.org/10.5539/ijbm.v12n8p182

\begin{abstract}
This study discussed the Capital Assets Pricing model (CAPM) and its ability to measure the required return, the researcher tested this model on Amazon Company listed in S\&P 500 during the period (2009-2016), to measure the impact of beta stock and market index return on the required return. Multiple regression model was used to test the effect of independent variables (Beta stock, Market Index Return) on the dependent variable (Required return), it should be noted that there is a statistically significant impact of the US stock market Return (S\&P500) and Amazon stock Beta factor on Amazon stock required return, and the study model explanatory was $20 \%$, this means that $20 \%$ of the changes in the required return are due to beta and market return, and $80 \%$ of the changes due to other factors, also find that CAPM can be applied on efficiency markets and huge companies.

The researcher recommends applying the variables of the study on a group of large companies in the S\&P 500 index, and looking for other factors that may affect the required return.
\end{abstract}

Keywords: CAPM, Amazon, Required return, Beta, Risk, S\&P500, Market Return, Pricing Model.

\section{Introduction}

Financial markets have an important role in the economic development process because of attracting investors and the accumulated savings and directing them to the right investments by the published information that reflect the market situation and the assets being traded in such a way that gives investors the best choice among the available investments especially in the efficient markets.

Having said this, investors look for an appropriate return that is commensurate with the risk in this investment. Therefore, investments must be evaluated before making a decision. There are many mechanisms that are used in financial analysis and determination of the required return on investments. The most important of these methods is the capital asset pricing model (CAPM), which is based on the required return measurement on a number of factors; nature of the relationship and correlation between the stock returns and market index returns, in addition to the investment risks that the model divided it into systematic risk and non-systematic risk. (Mullins, 1982).

This study was conducted to examine the ability of the capital asset pricing model in order to explain the changes in stocks returns, and its ability to price stocks by forecasting and measuring the required return by applying this model to an important company listed on the S\&P500 index, Amazon (2009-2016).

\subsection{Problem}

Investing in securities is not an easy work, because of the difficulty of estimating the return, especially with regard to the ordinary shares, which increases the degree of uncertainty for the investor and his sense of risk. Thus, in order to reduce the uncertainty of investors and encourage them to make investment decisions, there is a need to have scientific methods to evaluate investments, especially investment in the financial markets, as an important body in any economy in the world, especially efficient markets such as: the US stock market (S\&P 500), which measures the performance of the top 500 companies in the US stock market based on the market's value of shares traded on the NYSE and NASDAQ.

The main problem is to test CAPM's ability to explain changes in stock returns as a result of changes in market returns in S\&P500 and apply it to one of the major companies in this market, which is Amazon Co. 
The Study will try to answer the following questions:

1) Is there an impact of the market's return on the Amazon required return?

2) Is there an impact of Amazon's beta stock factor on Amazon's required return?

3) Can the CAPM model be applied in (S\&P 500) (Amazon Co).

\subsection{Importance}

The importance of the research is highlighted the CAPM model as the most important pricing method used to measure the required return in comparison with risk in the US stock market. The importance came from the model importance in assessing stocks and measuring the cost of financing. It can also guide investors to choose stocks that meet their investment needs, and to build efficient portfolios.

\subsection{Objective}

The objective of this study is to investigate the possibility of applying CAPM in the US stock market (S\&P500) and to clarify the mechanism by which this model can be applied to measure the required return.

\section{Literature Reviews}

\section{Capital Asset Pricing Model (CAPM)?}

Modern financial theory is based on two basic assumptions; the first one is that stock markets are efficient and full competition, the second one is that investors in these markets are rational investors and seek to maximize the yield within acceptable risk limits.

The first Assumption is assumed that the financial market is driven by buyers and sellers with a high degree of sophistication and understanding. The second hypothesis is assumed that investors who are interested in wealth and prefer an additional premium to the required return because of expecting more risks. (Turner A. el al, 2010)

The capital asset pricing model (CAPM) is based on the portfolio theory developed by Harry Markowitz (1959). The portfolio model requires a critical condition on the weights of assets in medium-efficient portfolios. CAPM based on a testable forecast on the relationship between risk and required return by choosing a portfolio that should be effective if the asset prices are clear to the market for all assets (Fama, French, 2004). (Sattar, 2017).

Sharpe (1964), Lintner (1965) and Black (1972) developed the CAPM model, which is the reliable model to Measure the required return, which reflects the cost of equity financing. This model measures the risk of the securities by measuring the sensitivity of the return of the security to the change in market's return, the market's risk in this model measured by Beta Coefficient (B). CAPM model was based on a set of assumptions :(Ross el al, 2008). (Al Naimi el al, 2009), (Bodie, Kane, 2010)

1) All market investors are planning the same holding period.

2) Lending and borrowing are carried out in accordance with the risk-free rate of return.

3) Information symmetry and full efficiency of financial markets.

4) All investors analyse the securities in the same way and have the same expectations.

5) Absence of taxes and the costs of financial brokerage.

6) All investors are characterized by rationality, which means that the investment design based on comparison between return and risk.

7) Investors do not affect the market individually.

The CAPM includes a set of concepts that translate required return calculation, as follows:

First, the Security Market Line (SML). This concept captures the relationship between the required return and the market risk expressed by Beta Coefficient. Here, it must be noted that the model divides the risk into two types: (Hadad, 2015).

Non-systemic risk: They can be called firm specific risk or diversification risk, this type of risk happen because of the financial and operating decisions taken by the company itself. The financial risks related to financial leverage, and capital structure, the operation risk related to operations Administrative and competitive with other companies. This type of risk can't be predicted but can be reduced through diversification and portfolio formation in a way that minimizes risks in a way that the portfolio contains assets with a weak correlation coefficient between these assets according to Markowitz's theory.

Systematic Risk: This type of risk is caused by market factors and affects the market in general, and does not 
affect one company alone. It is linked to economic changes, especially macroeconomic indicators as well as natural disasters, but can't reduce those risks through diversification but by predicting and hedging them.

The systematic risk is measured through the beta coefficient of the company's shares by using the trend of the security market line or using the covariance of the stock's return and market's return as in the following equation, (Fama, French, 2004).:

$$
B_{j}=\quad \frac{{ }_{J, m} \underline{\sigma}_{j} \underline{\sigma}_{m} \rho}{\underline{\sigma}_{m}^{2}}
$$

\section{Whereas:}

$\mathbf{B}_{\mathbf{j}}$ : Beta coefficient of the company's shares.

$\mathbf{P}_{\mathrm{J}, \mathrm{m}}$ : Correlation coefficient between stock and market.

\section{$\sigma_{\mathrm{j}}:$ Firm Stock risk.}

$\sigma_{\mathrm{m}}$ : Market risk.

$\boldsymbol{\sigma}_{\mathrm{m}}^{2}$ : Market variance.

The beta-market coefficient is constant and equal one (1), and can be proved by using the previous equation as follows (Ross, el al, 2008)

$$
B_{m}=\frac{{ }_{m \cdot m} \sigma_{m}^{2} \rho}{\underline{\sigma}_{m}^{2}}
$$

So the equation becomes as follows (because the correlation coefficient of the original with itself is equal to one:

$$
B_{m}=\rho_{m, m} \quad \text { So } \quad B_{m}=1
$$

\section{Whereas:}

$\mathbf{B}_{\mathbf{m}}$ : Market Beta

$\boldsymbol{\rho}_{\mathbf{m}, \mathbf{m}}$ : Market correlation with itself

The portfolio risk can be measured according to the beta by the following equation (Hadad, 2015).

$$
B_{P}=\sum_{j=1}^{n}\left(W_{j} x B_{j}\right)
$$

\section{Whereas:}

\section{B $_{\mathbf{P}}$ : Portfolio's risk According to CAPM}

$\mathbf{W}_{\mathrm{j}} \mathbf{x}$ : The weight of the stock in the portfolio.

$\mathbf{B}_{\mathbf{j}}$ : Beta coefficient of the company's shares.

The stock's return response to changes in market's returns depends on the beta-stock coefficient. If beta is greater than 1, the change in the stock's return is greater than the change in market's return. But if it is smaller than 1, the change in stock's return is less than the change in market's returns, whereas if the stock beta is equal to 1 , that means, the change in stock's return is equal to the change in the market's return, because the value of the beta depends on the coefficient of the correlation between the stock's return and market's returns (Hadad, 2015).

The CAPM model provides the required return through the security market line curve equation as follows:

$$
K_{j}=R_{f}+B_{j}\left(K_{m}-R_{f}\right)
$$

\section{Where is:}

$\mathbf{K}_{\mathbf{j}}$ : Required stock's return. 
$\mathbf{R}_{\mathbf{f}}$ : Risk free rate.

$\mathbf{B}_{\mathbf{j}}$ : Stock beta coefficient.

$\mathbf{K}_{\mathbf{m}}$ : Return on market portfolio.

From the equation (5) the market's risk premium and the stock's risk premium can be calculate as follows: (Zenner el al.2008).

Market risk premium: Market return - risk free rate.

Stock Risk Premium: Market risk premium * Beta stock market.

The variables of the CAPM model can be graphically represented by the security market line (SML), which is very useful when applying the CAPM model, or when applying modern portfolio formation techniques based on the beta factor.

Figure 1 shows the relationship between the beta factor and the required return. It is worth mentioning that there is controversy regarding the use of beta as a measure of risk and required return.

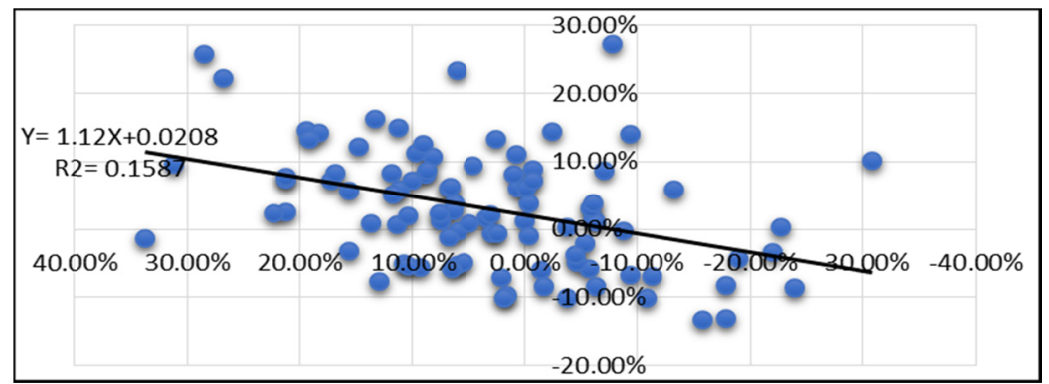

Figure 1. Amazon Beta

Source: Based on the results of the analysis 2017.

\subsection{Description of Amazon Company}

"Amazon.com, Inc. engages in the retail sale of consumer products and subscriptions in North America and internationally. It operates through the North America, International, and Amazon Web Services (AWS) segments. The company sells, merchandise and content purchased for resale from vendors, as well as those offered by third-party sellers through retail Websites, such as amazon.com, amazon.ca, amazon.com.mx, amazon.com.au, amazon.com.br, amazon.cn, amazon.fr, amazon.de, amazon.in, amazon.it, amazon.co.jp, amazon.nl, amazon.es, and amazon.co.uk. It also manufactures and sells electronic devices, including kindle e-readers, fire tablets, fire TVs, and echo; and provides Kindle Direct Publishing, an online service that allows independent authors and publishers to make their books available in the Kindle Store. In addition, the company offers programs that enable sellers to sell their products on its Websites, as well as their own branded Websites; and programs that allow authors, musicians, filmmakers, app developers, and others to publish and sell content. Further, it provides compute, storage, database, and other AWS services, as well as fulfillment, publishing, digital content subscriptions, advertising, and co-branded credit card agreements services. Additionally, the company offers Amazon Prime, an annual membership program, which provides free shipping of various items; access to unlimited streaming of movies and TV episodes; and other services. It serves consumers, sellers, developers, enterprises, and content creators. The company was founded in 1994 and is headquartered in Seattle, Washington". (Yahoo finance, 2017).

Table 1. An important indicators about Amazon.

\begin{tabular}{llll}
\hline Valuation Measures & & & \\
\hline Market Cap (intraday) 5 & $458.78 \mathrm{~B}$ & Profit Margin & $1.81 \%$ \\
Enterprise Value 3 & N/A & Operating Margin (ttm) & $2.89 \%$ \\
Trailing P/E & 180.76 & Management Effectiveness & \\
Forward P/E 1 & 84.94 & Return on Assets (ttm) & $3.62 \%$ \\
PEG Ratio (5 yr expected) 1 & 5.25 & Return on Equity (ttm) & $14.18 \%$ \\
Price/Sales (ttm) & 3.22 & Income Statement & \\
\hline
\end{tabular}




\begin{tabular}{|c|c|c|c|c|}
\hline Price/Book (mrq) & 21.17 & Revenue (ttm) & $142.57 \mathrm{~B}$ & \\
\hline Enterprise Value/Revenue 3 & N/A & Revenue Per Share (ttm) & 299.84 & \\
\hline Enterprise Value/EBITDA 6 & N/A & Quarterly Revenue Growth (yoy) & $22.60 \%$ & \\
\hline Financial Highlights & & Gross Profit (ttm) & $47.72 \mathrm{~B}$ & \\
\hline Fiscal Year & & EBITDA & $12.22 \mathrm{~B}$ & \\
\hline Fiscal Year Ends & Dec 31,2016 & Net Income Avi to Common (ttm) & $2.58 \mathrm{~B}$ & \\
\hline Most Recent Quarter (mrq) & Mar 31, 2017 & Diluted EPS (ttm) & 5.31 & \\
\hline \multicolumn{5}{|l|}{ Profitability } \\
\hline \multicolumn{5}{|l|}{ Trading Information } \\
\hline Beta & & 1.39 & Avg Vol (10 day) 3 & $3.75 \mathrm{M}$ \\
\hline 52-Week Change 3 & & $37.57 \%$ & Shares Outstanding 5 & $477.98 \mathrm{M}$ \\
\hline S\&P500 52-Week Change 3 & & $15.51 \%$ & Float & $397.69 \mathrm{M}$ \\
\hline 52 Week High 3 & & 970.06 & $\%$ Held by Insiders 1 & $17.82 \%$ \\
\hline 52 Week Low 3 & & 682.12 & $\%$ Held by Institutions 1 & $67.50 \%$ \\
\hline 50-Day Moving Average 3 & & 924.09 & Shares Short 3 & $5.49 \mathrm{M}$ \\
\hline 200-Day Moving Average 3 & & 834.82 & Short Ratio 3 & 2.09 \\
\hline Share Statistics & & & Short $\%$ of Float 3 & $1.62 \%$ \\
\hline Avg Vol (3 month) 3 & & $3.27 \mathrm{M}$ & Shares Short (prior month) 3 & $5.91 \mathrm{M}$ \\
\hline
\end{tabular}

Sorce: yahoo finance 2017 .

There is a theoretical debate about the impact of the risk on the required return according to the CAPM's theory. For example a research of Mashriki, Shehab, (2014), test (CAPM), by using the monthly excess returns of (8) companies listed in (DSE), for the period of (2010-2013), and the monthly excess return of (DSE) index (DWX) for the same period. The researcher concluded that there is a significant relation between the volatility of the market's return and the volatility of the returns of stocks of the examined companies, But the researcher also concluded that (CAPM) is not valid in (DSE), because of the failure in the statistical test. That the constant of the regression equation is not equal to zero and the slope of the security market line is not equal to the average excess return of the stocks of examined companies. An article for Rafael el al, (2014), integrates the ideas from two major lines of research on cost of equity and asset pricing: multi-factor models and ex ante accounting models. The earnings/price ratio is used as a proxy for the ex ante cost of equity, in order to explain realized returns of Brazilian companies within the period (1995 -2013). The finding was that stocks with high (low) earnings/price ratios have higher (lower) risk-adjusted realized returns, already controlled by the capital asset pricing model's beta. The results show that selecting stocks based on high earnings/price ratios has led to significantly higher risk-adjusted returns in the Brazilian market, with average abnormal returns close to $1.3 \%$ per month. The researchers conclude that such a risk factor is significant to explain returns on portfolios, even when controlled by size and market/book ratios. Models including the high earnings minus low earnings risk factor were better to explain stock's returns in Brazil when compared to the capital asset pricing model and to the Fama and French three-factor model, having the lowest number of significant intercepts.

In a research for Fama, French, (2004), CAPM estimates of the cost of equity for high beta stocks are too high (relative to historical average returns) and estimates for low beta stocks are too low. Similarly, if the high average returns on value stocks (with high book-to-market ratios) imply high expected returns, CAPM cost of equity estimates for such stocks are too low. A study for Kapil, Sakshi, (2010) examines the (CAPM) for the Indian stock market using monthly stock returns from 278 companies of BSE 500 Index listed on the Bombay stock exchange for the period of January 1996 to December 2009. The findings of this study are not substantiating the theory's basic result that higher risk (beta) is associated with higher levels of return. The model does explain, however, excess returns and thus lends support to the linear structure of the CAPM equation. The theory's prediction for the intercept is that it should equal zero and the slope should equal the excess returns on the market portfolio. The results of the study lead to negate the above hypotheses and offer evidence against the CAPM.

The tests conducted to examine the nonlinearity of the relationship between return and betas bolster the hypothesis that the expected return-beta relationship is linear. Additionally, this study investigates whether the CAPM adequately captures all-important determinants of returns including the residual variance of stocks. The results exhibit that residual risk has no effect on the expected returns of portfolios.

The research of Al-Jameel, (2009) used the actual data of Kuwait capital market in estimating the capital asset 
pricing model. The application has three sides; the first one covered all companies listed in the market and the second side focused on the portfolios building during the research period, whereas the third took the market indices. However, this is the implication of the research objective which is studying the relationship between return and risk under the methodology of the capital asset pricing model. The research analysis indicated two important issues, the determination of beta coefficient for individual stock and for the portfolios. The result is significant in different levels of probability within the traditional capital asset pricing model. Perold, (2004), says that the Capital Asset Pricing Model is a fundamental contribution for understanding of the determinants of asset prices. The CAPM tells that ownership of assets by diversified investors lowers their expected returns and raises their prices. Moreover, investors who hold undiversified portfolios are likely to be taking risks for which they are not being rewarded. As a result of the model, and despite its mixed empirical performance, he says that we now think differently about the relationship between expected returns and risk; we think differently about how investors should allocate their investment portfolios; and we think differently about questions such as performance measurement and capital budgeting.

Table 2. Summary of the results of related researches

\begin{tabular}{|c|c|c|}
\hline Researcher and Research Year & Variable & Result \\
\hline $\begin{array}{l}\text { Mashriki, Shehab, (2014), (8) companies listed in } \\
\text { (DSE), for the period of }(2010-2013)\end{array}$ & market return & $\begin{array}{l}\text { Significant relation between the volatility } \\
\text { of the market return and the volatility of } \\
\text { the returns of stocks of the examined } \\
\text { companies. }\end{array}$ \\
\hline $\begin{array}{l}\text { Rafael el al, (2014), Brazilian companies within the } \\
\text { period (1995 -2013) }\end{array}$ & cost of equity & $\begin{array}{l}\text { stocks with high (low) earnings/price ratios } \\
\text { have higher (lower) risk-adjusted realized } \\
\text { returns, already controlled by the capital } \\
\text { asset pricing model's beta }\end{array}$ \\
\hline Fama, French, (2004). & cost of equity, beta stocks & $\begin{array}{l}\text { if the high average returns on value stocks } \\
\text { (with high book-to-market ratios) imply } \\
\text { high expected returns }\end{array}$ \\
\hline $\begin{array}{l}\text { Kapil, Sakshi, (2010), Indian stock market using } \\
\text { monthly stock returns from } 278 \text { companies of BSE } \\
500 \text { Index listed on the Bombay stock exchange for } \\
\text { the period of January } 1996 \text { to December } 2009 \text {. }\end{array}$ & stock returns, Beta & $\begin{array}{l}\text { not substantiating the theory's basic result } \\
\text { that higher risk (beta) is associated with } \\
\text { higher levels of return }\end{array}$ \\
\hline $\begin{array}{l}\text { Al-Jameel, (2009) used the actual data of Kuwait } \\
\text { capital market. }\end{array}$ & Return, Beta & $\begin{array}{l}\text { The result is significant in different levels } \\
\text { of probability within the traditional capital } \\
\text { asset pricing model }\end{array}$ \\
\hline Perold, (2004). & Expected Risk, Return & $\begin{array}{l}\text { the Capital Asset Pricing Model is a } \\
\text { fundamental contribution for } \\
\text { understanding of the determinants of asset } \\
\text { prices }\end{array}$ \\
\hline
\end{tabular}

\section{Methodology}

Descriptive and analytical approach used, based on the financial data published from the S\&P500 during the period (2009-2016) to test the hypotheses of the study, in addition to the previous literature that discussed the subject of the study. Financial analysis used appropriate financial ratios, by using Excel program to calculate the variables of study, as well as statistical analysis to analyze the data collected using the (SPSS) to test the model of the study and hypotheses. This will be applied to the US Company Amazon for the period as a study.

\subsection{Hypotheses}

The 1st hypothesis: There is no statistically significant impact of the US stock's market return (S\&P500) on Amazon share required return.

The 2nd hypothesis: There is no statistically significant effect of Amazon beta factor on Amazon shares required return.

The 3rd hypothesis: CAPM can't be applied to the US stock market (S\&P 500). 


\subsection{Study Model}

The model of the study will be based on the effect of the independent variables on the dependent variable by using multiple linear regression as shown in Figure (1).

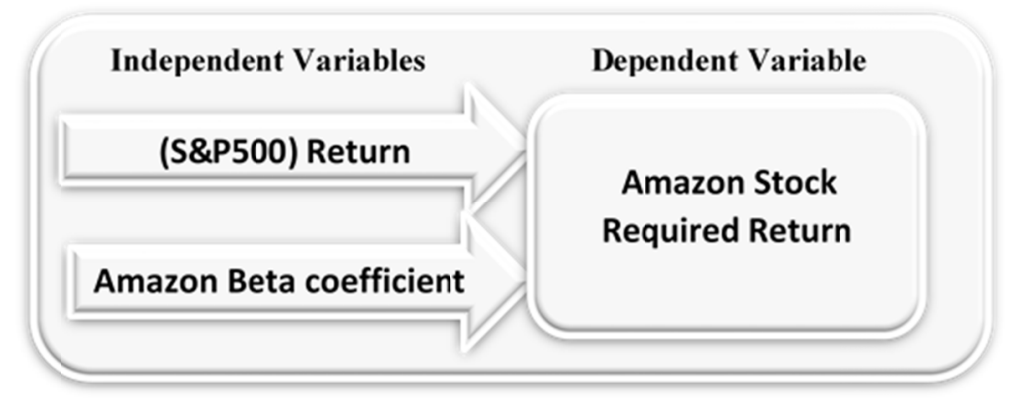

Figure 2. Descriptive model of the study variables

\subsection{Variables}

Independent variables: Return of the S \& P500 index, a beta coefficient for Amazon.

Dependent variable: Amazon required return.

Multiple linear regression equation can be used to analyze the effect of the independent variables on the dependent variables as in the following equations: (Mashriki \& Shehab, 2014)

$$
R i t=\alpha 0+B_{1} * R m t+B_{2} * B i t+e i t
$$

\section{Whereas:}

Rit: company Stock required Return.

Rmt: market index Return.

Bit: Company stock Beta Coefficient.

The researcher performed the following procedures to apply the research model to the Amazon Company.

First: Calculation of CAPM equation (5) variables.

\section{Whereas:}

$\mathbf{R}_{\mathbf{f}}$ : Is the risk-free rate of return, where the researcher relied on the rate of return on US Treasury bonds of 4.25\%, (Treasury Direct, 2017).

$\mathbf{B}_{\mathbf{j}}$ : Amazon Beta, which was calculated using the appropriate financial and statistical functions on the Excel program, which reached 1.12, (Amazon Stock Beta calculated by the researcher depends on the data published in S\&P 500).

$\mathbf{K}_{\mathbf{m}}$ : market Return index calculated based on the data published in S\&P500.

\section{Statistical Analysis}

Table 3. Correlations

\begin{tabular}{llll}
\hline & $\mathrm{Kj}$ & $\mathrm{KM}$ & Beta \\
\hline $\mathrm{Kj}$ & 1.000 & .305 & .318 \\
$\mathrm{KM}$ & .305 & 1.000 & -.026 \\
Beta & .318 & -.026 & 1.000 \\
\hline
\end{tabular}

Source: Based on the results of the analysis 2017.

Table 3 shows the correlation between the study variables, the matrix of correlation) has been studied in order to make sure there's no strong relationship between each of the independent variables, so the researcher continued the analysis process 
Table 4. Model summary

\begin{tabular}{lllll}
\hline Model & R & R Square & Adjusted R Square & Std. Error of the Estimate \\
\hline 1 & $.446(\mathrm{a})$ & .199 & .182 & .03218 \\
\hline a Predictors: (Constant), Beta, RM. & & \\
Source: Based on the results of the analysis 2017.
\end{tabular}

Table 4 shows the explanatory power of the model through Adjusted R Square, which is about $20 \%$, this means that $20 \%$ of the changes in the required return are due to beta and market return, and $80 \%$ of the changes due to other factors.

Table 5. F test, ANOVA (b)

\begin{tabular}{lllllll}
\hline Model & & Sum & of & df & Mean Square & F \\
& & Squares & & & \\
\hline 1 & Regression & .024 & 2 & .012 & 11.443 \\
& Residual & .095 & 92 & .001 & \\
& Total & .119 & 94 & & \\
\hline
\end{tabular}

a Predictors: (Constant), Beta, RM.

b Dependent Variable: K.

Source: Based on the results of the analysis 2017.

Table 5 shows that the level of significant is (0.00), less than 5\%. This means that the model is acceptable.

\subsection{Hypotheses Test}

Table 6. Results of evaluating the model

\begin{tabular}{lllllll}
\hline Model & & B & Std. Error & Beta & t & Sig. \\
\hline $\mathbf{1}$ & (Constant) & -.003 & .004 & & -.841 & .403 \\
& KM & .090 & .027 & .313 & 3.356 & .001 \\
& Beta & .037 & .011 & .326 & .001 \\
\hline
\end{tabular}

a Dependent Variable: $\mathrm{Kj}$.

Source: Based on the results of the analysis 2017.

Table 6 shows the results of the T- test which shows the effect of the independent variables (Beta) and (KM) on the dependent variable $(\mathrm{Kj})$.

The 1st Null Hypothesis: There is no statistically significant impact of the US stock market index Return (S\&P500) on Amazon stock required return.

Table (6). Shows the result of the examination of this hypothesis. The above mentioned results indicate that the $\mathrm{P}$ value (Sig*) (corresponding to 0.001 ) is less than (-1) with a confidence level of 5\%. This means that the Null hypothesis is rejected and the alternative hypothesis is accepted.

The 2nd sub Null Hypothesis: There is no statistically significant impact of Amazon Beta on Amazon stock required return.

Table (6). Shows the result of the examination of this hypothesis. The above mentioned results indicate that the $\mathrm{P}$ value (Sig*) (corresponding to 0.001 ) is less than (-1) with a confidence level of $5 \%$. This means that the Null hypothesis is rejected and the alternative hypothesis is accepted. 
Table 7. Amazon actual and required return 2009-2016

\begin{tabular}{|c|c|c|c|c|c|c|c|c|c|c|c|}
\hline Date & $\begin{array}{l}\text { Amazon } \\
\text { Return }\end{array}$ & $\begin{array}{l}\text { Required } \\
\text { (CAPM) }\end{array}$ & Return & Date & $\begin{array}{l}\text { Amazon } \\
\text { Return }\end{array}$ & $\begin{array}{l}\text { Required } \\
(\mathrm{CAPM})\end{array}$ & Return & Date & $\begin{array}{l}\text { Amazon } \\
\text { Return }\end{array}$ & $\begin{array}{l}\text { Required } \\
\text { (CAPM) }\end{array}$ & Return \\
\hline $\begin{array}{l}\text { Dec- } \\
16\end{array}$ & 0.001 & 0.046 & & $\begin{array}{l}\text { Apr-1 } \\
4\end{array}$ & 0.010 & 0.037 & & $\begin{array}{l}\text { Aug- } \\
11\end{array}$ & 0.033 & 0.017 & \\
\hline $\begin{array}{l}\text { Nov- } \\
16\end{array}$ & 0.050 & 0.057 & & $\begin{array}{l}\text { Mar- } \\
14\end{array}$ & 0.047 & 0.038 & & $\begin{array}{l}\text { Jul-1 } \\
1\end{array}$ & 0.088 & 0.017 & \\
\hline $\begin{array}{l}\text { Oct-1 } \\
6\end{array}$ & 0.057 & 0.020 & & $\begin{array}{l}\text { Feb-1 } \\
4\end{array}$ & 0.019 & 0.064 & & $\begin{array}{l}\text { Jun-1 } \\
1\end{array}$ & 0.040 & 0.019 & \\
\hline $\begin{array}{l}\text { Sep-1 } \\
6\end{array}$ & 0.089 & 0.031 & & $\begin{array}{l}\text { Jan-1 } \\
4\end{array}$ & 0.041 & 0.009 & & $\begin{array}{l}\text { May- } \\
11\end{array}$ & 0.004 & 0.024 & \\
\hline $\begin{array}{l}\text { Aug- } \\
16\end{array}$ & 0.014 & 0.033 & & $\begin{array}{l}\text { Dec- } \\
13\end{array}$ & 0.039 & 0.050 & & $\begin{array}{l}\text { Apr-1 } \\
1\end{array}$ & 0.087 & 0.053 & \\
\hline $\begin{array}{l}\text { Jul-1 } \\
6\end{array}$ & 0.060 & 0.058 & & $\begin{array}{l}\text { Nov- } \\
13\end{array}$ & 0.021 & 0.053 & & $\begin{array}{l}\text { Mar- } \\
11\end{array}$ & 0.039 & 0.032 & \\
\hline $\begin{array}{l}\text { Jun-1 } \\
6\end{array}$ & 0.010 & 0.032 & & $\begin{array}{l}\text { Oct-1 } \\
3\end{array}$ & 0.072 & 0.063 & & $\begin{array}{l}\text { Feb-1 } \\
1\end{array}$ & 0.022 & 0.057 & \\
\hline $\begin{array}{l}\text { May- } \\
16\end{array}$ & 0.096 & 0.044 & & $\begin{array}{l}\text { Sep-1 } \\
3\end{array}$ & 0.012 & 0.055 & & $\begin{array}{l}\text { Jan-1 } \\
1\end{array}$ & 0.058 & 0.048 & \\
\hline $\begin{array}{l}\text { Apr-1 } \\
6\end{array}$ & 0.111 & 0.035 & & $\begin{array}{l}\text { Aug- } \\
13\end{array}$ & 0.029 & 0.012 & & $\begin{array}{l}\text { Dec- } \\
10\end{array}$ & 0.026 & 0.081 & \\
\hline $\begin{array}{l}\text { Mar- } \\
16\end{array}$ & 0.074 & 0.081 & & $\begin{array}{l}\text { Jul-1 } \\
3\end{array}$ & 0.052 & 0.071 & & $\begin{array}{l}\text { Nov- } \\
10\end{array}$ & 0.062 & 0.033 & \\
\hline $\begin{array}{l}\text { Feb-1 } \\
6\end{array}$ & 0.059 & 0.030 & & $\begin{array}{l}\text { Jun-1 } \\
3\end{array}$ & 0.047 & 0.020 & & $\begin{array}{l}\text { Oct-1 } \\
0\end{array}$ & 0.052 & 0.060 & \\
\hline $\begin{array}{l}\text { Jan-1 } \\
6\end{array}$ & 0.132 & 0.003 & & $\begin{array}{l}\text { May- } \\
13\end{array}$ & 0.023 & 0.048 & & $\begin{array}{l}\text { Sep-1 } \\
0\end{array}$ & 0.258 & 0.097 & \\
\hline $\begin{array}{l}\text { Dec- } \\
15\end{array}$ & 0.017 & 0.019 & & $\begin{array}{l}\text { Apr-1 } \\
3\end{array}$ & 0.060 & 0.045 & & $\begin{array}{l}\text { Aug- } \\
10\end{array}$ & 0.059 & 0.003 & \\
\hline $\begin{array}{l}\text { Nov- } \\
15\end{array}$ & 0.062 & 0.034 & & $\begin{array}{l}\text { Mar- } \\
13\end{array}$ & 0.023 & 0.059 & & $\begin{array}{l}\text { Jul-1 } \\
0\end{array}$ & 0.079 & 0.081 & \\
\hline $\begin{array}{l}\text { Oct-1 } \\
5\end{array}$ & 0.223 & 0.094 & & $\begin{array}{l}\text { Feb-1 } \\
3\end{array}$ & 0.047 & 0.040 & & $\begin{array}{l}\text { Jun-1 } \\
0\end{array}$ & 0.129 & 0.007 & \\
\hline $\begin{array}{l}\text { Sep-1 } \\
5\end{array}$ & 0.002 & 0.013 & & $\begin{array}{l}\text { Jan-1 } \\
3\end{array}$ & 0.047 & 0.068 & & $\begin{array}{l}\text { May- } \\
10\end{array}$ & 0.085 & 0.021 & \\
\hline $\begin{array}{l}\text { Aug- } \\
15\end{array}$ & 0.043 & 0.010 & & $\begin{array}{l}\text { Dec- } \\
12\end{array}$ & 0.005 & 0.038 & & $\begin{array}{l}\text { Apr-1 } \\
0\end{array}$ & 0.010 & 0.044 & \\
\hline $\begin{array}{l}\text { Jul-1 } \\
5\end{array}$ & 0.235 & 0.047 & & $\begin{array}{l}\text { Nov- } \\
12\end{array}$ & 0.082 & 0.035 & & $\begin{array}{l}\text { Mar- } \\
10\end{array}$ & 0.147 & 0.077 & \\
\hline $\begin{array}{l}\text { Jun-1 } \\
5\end{array}$ & 0.011 & 0.019 & & $\begin{array}{l}\text { Oct-1 } \\
2\end{array}$ & 0.084 & 0.019 & & $\begin{array}{l}\text { Feb-1 } \\
0\end{array}$ & 0.056 & 0.054 & \\
\hline $\begin{array}{l}\text { May- } \\
15\end{array}$ & 0.018 & 0.041 & & $\begin{array}{l}\text { Sep-1 } \\
2\end{array}$ & 0.024 & 0.050 & & $\begin{array}{l}\text { Jan-1 } \\
0\end{array}$ & 0.068 & 0.008 & \\
\hline $\begin{array}{l}\text { Apr-1 } \\
5\end{array}$ & 0.134 & 0.039 & & $\begin{array}{l}\text { Aug- } \\
12\end{array}$ & 0.064 & 0.048 & & $\begin{array}{l}\text { Dec- } \\
09\end{array}$ & 0.010 & 0.048 & \\
\hline $\begin{array}{l}\text { Mar- } \\
15\end{array}$ & 0.021 & 0.021 & & $\begin{array}{l}\text { Jul-1 } \\
2\end{array}$ & 0.022 & 0.040 & & $\begin{array}{l}\text { Nov- } \\
09\end{array}$ & 0.144 & 0.074 & \\
\hline $\begin{array}{l}\text { Feb-1 } \\
5\end{array}$ & 0.072 & 0.072 & & $\begin{array}{l}\text { Jun-1 } \\
2\end{array}$ & 0.073 & 0.056 & & $\begin{array}{l}\text { Oct-0 } \\
9\end{array}$ & 0.273 & 0.015 & \\
\hline $\begin{array}{l}\text { Jan-1 } \\
5\end{array}$ & 0.142 & 0.012 & & $\begin{array}{l}\text { May- } \\
12\end{array}$ & 0.082 & 0.007 & & $\begin{array}{l}\text { Sep-0 } \\
9\end{array}$ & 0.150 & 0.059 & \\
\hline $\begin{array}{l}\text { Dec- } \\
14\end{array}$ & 0.084 & 0.029 & & $\begin{array}{l}\text { Apr-1 } \\
2\end{array}$ & 0.145 & 0.027 & & $\begin{array}{l}\text { Aug- } \\
09\end{array}$ & 0.053 & 0.057 & \\
\hline $\begin{array}{l}\text { Nov- } \\
14\end{array}$ & 0.109 & 0.052 & & $\begin{array}{l}\text { Mar- } \\
12\end{array}$ & 0.127 & 0.054 & & $\begin{array}{l}\text { Jul-0 } \\
9\end{array}$ & 0.025 & 0.083 & \\
\hline Oct-1 & 0.053 & 0.047 & & Feb-1 & 0.076 & 0.062 & & Jun- 0 & 0.073 & 0.031 & \\
\hline
\end{tabular}




\begin{tabular}{|c|c|c|c|c|c|c|c|c|}
\hline \multicolumn{3}{|l|}{4} & \multicolumn{3}{|l|}{2} & \multicolumn{3}{|l|}{9} \\
\hline Sep-1 & 0.049 & 0.023 & Jan-1 & 0.123 & 0.066 & May- & 0.031 & 0.068 \\
\hline 4 & & & 2 & & & 09 & & \\
\hline Aug- & 0.083 & 0.060 & Dec- & 0.100 & 0.037 & Apr-0 & 0.096 & 0.103 \\
\hline 14 & & & 11 & & & 9 & & \\
\hline Jul-1 & 0.036 & 0.023 & Nov- & 0.099 & 0.025 & Mar- & 0.134 & 0.076 \\
\hline 4 & & & 11 & & & 09 & & \\
\hline Jun-1 & 0.039 & 0.047 & Oct-1 & 0.013 & 0.109 & Feb-0 & 0.101 & 0.037 \\
\hline 4 & & & 1 & & & 9 & & \\
\hline May- & 0.028 & 0.047 & Sep-1 & 0.005 & 0.018 & & & \\
\hline 14 & & & 1 & & & & & \\
\hline
\end{tabular}

Source: Based on the results of the analysis 2017.

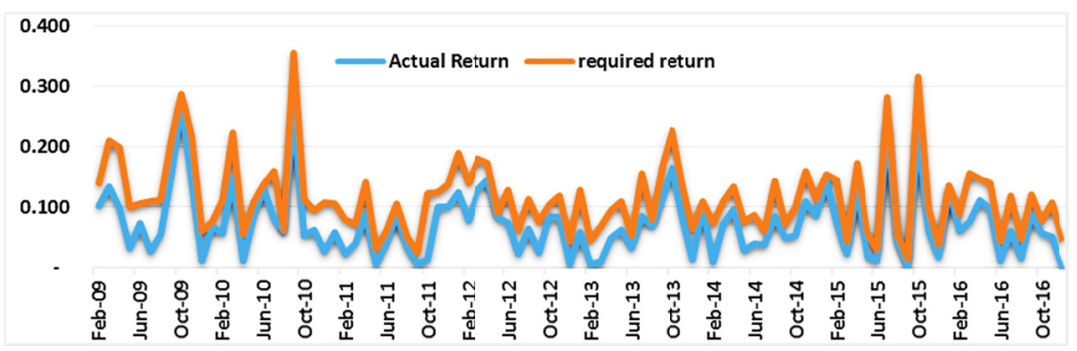

Figure 3. Amazon actual return \& required return

Source: Based on the results of the analysis 2017.

The 3rd sub Null Hypothesis: CAPM cannot be applied to the US stock market (S\&P500).

Table 7 shows that there is a convergence between the required return and the actual return of Amazon Co. during the study period, and that the required and actual returns are moving in the direction of the trend as shown above. This means that the Null hypothesis is rejected and the alternative hypothesis is accepted.

\section{Results}

There is a statistically significant impact of the US stock market Return (S\&P500) on Amazon stock required return.

There is a statistically significant impact of Amazon Beta factor on Amazon stock required return.

1) CAPM can be applied to the US stock market (S\&P500).

2) $20 \%$ of the changes in the required return are due to beta and market return, and $80 \%$ of the changes due to other factors.

3) CAPM model can be applied on efficiency markets and huge companies.

4) $20 \%$ of the changes in the required return are due to beta and market return, and $80 \%$ of the changes due to other factors.

5) CAPM model can be applied on efficiency markets and huge companies.

\section{Recommendation}

The researcher recommends that investors in financial markets not to rely on capital asset pricing model to evaluate and make decision, even if the study shows its ability of CAPM to explain the changes in stock's returns, but rely on additional models to support investment decision making, like cash flow discount model, accounting valuation, profit multiplier, arbitrage......etc.

Researcher also recommends future researchers to expanding in-depth academic research into the market capitalization of stocks to include other determinants not covered in the study, such as the risk-free rate of return, the type of investors, the nature of the prevailing economic situation, and other factors, and returning the same analysis to a group of huge companies in S\&P500 market, or in another financial market. 


\section{References}

Al-Mashreqi, H., \& Shehab, A. (2014). Capital Asset Pricing Model Test in the Damascus Stock Exchange. Al-Ba'ath University, 63(1), 255-286.

Sattar, M. (2017). CAPM Vs Fama-French Three-Factor Model: An Evaluation of Effectiveness in Explaining Excess Return in Dhaka Stock Exchange. International of Business and Management, 12(5), 119-129. https://doi.org/10.5539/ijbm.v12n5p119

Fama, E., \& French, K. (2004). The Capital Asset Pricing Model: Theory and Evidence. Economic Perspectives, 18(3), 25-46. https://doi.org/10.1257/0895330042162430

Choudhaary, K., \& Choudhaary, S. (2010). Testing Capital Asset Pricing Model: Empirical Evidences from Indian Equity Market. Business and Economics, 3(6), 127-138. http://ejbe.org/EJBE2010Vo103No06p127CHOUDHARY-CHOUDHARY.pdf.

Al-Jameel, S. (2009). Application of Capital Asset Pricing Model in Kuwait Capital Market. Development of Rafidain, University of Mosul, 31(94), 253-270.

Perold, A. (2004). The Capital Asset Pricing Model. Economic Perspectives, 18: (3), 3-24. https://doi.org/10.1257/0895330042162340

Bodie, Z. A., \& Marcus, A. J. (2010). Essentials of Investments, (8th ed.), McGraw-Hill/ Irwin, New York.

Al-Nuaimi, A., \& Arshad, F. (2009). Advanced Financial Management (2nd ed.), Amman, Jordan.

Ross, S, Westerfield, R., Jaffe, J., \& Jordan, B. (2008). Modern Financial Management (8th ed.), McGraw-Hill/ Irwin, New York.

Hadad, F. (2015). Corporat Finance (4th ed.). Al Hamed, Amman, Jordan.

Mullins, D. W. (1982). Does the Capital Asset Pricing Model Work? Harvard Business School. Retrieved from https://hbr.org/1982/01/does-the-capital-asset-pricing-model-work

Turner A., Haldane, A, Woolley, P., Wadhwani S., Goodhart, C. H., Smithers, A., Large, A., Kay, J., \& Wolf, M., Boone, P., Johnson, S., \& Layard, R. (2010). The future of finance and the theory that underpins it. Retrieved from https://harr123et.files.wordpress.com/2010/07/futureoffinance5.pdf

Ross, S., Westerfield, R. W., Jeffrey F. J., \& Bradford, D. (2008). Modern Financial Management (8th ed), New York: McGraw-Hill/Irwin.

Zenner, M., Hill, S., \& Clark, J., \& Mago, N. (2008). The Most Important Number in Finance the Quest for the Market Risk Premium, J. P. Morgan Securities Inc. Retrieved from https://www.jpmorgan.com/jpmpdf/1320675769380.pdf

Noda, R. F., Martelanc, R., \& Kayo, E. K. (2014, January) The Earnings/Price Risk Factor in Capital Asset Pricing Models, Paper presented at the BALAS Annual Conference, Port of Spain, Retrieved from http://www.scielo.br/pdf/rcf/2015nahead/1808-057x-rcf-201412060.pdf

Treasury Direct. (2017). Retrieved from from https://www.treasurydirect.gov/indiv/research/indepth/tbonds/res_tbond_rates.htm

Yahoo Finance. (2017). Retrieved from https://finance.yahoo.com/quote/AMZN?p=AMZN.

Yahoo Finance. (2017). Retrieved from https://finance.yahoo.com/quote/AMAZ/profile?p=AMAZ

\section{Copyrights}

Copyright for this article is retained by the author(s), with first publication rights granted to the journal.

This is an open-access article distributed under the terms and conditions of the Creative Commons Attribution license (http://creativecommons.org/licenses/by/4.0/). 